\title{
Political Relation among the State and International Sports Organizations: The 2014 FIFA World Cup Event in Brazil
}
Authors' contribution:
A) conception and design of the study
B) acquisition of data
C) analysis and interpretation of data
D) manuscript preparation
E) obtaining funding

\author{
Felipe Canan ${ }^{\text {A-E }}$, Allan Fernando Zardo da Silva ${ }^{\text {A-E }}$, \\ Fernando Augusto Starepravo ${ }^{\mathrm{A}-\mathrm{E}}$ \\ University of Maringá, Paraná, Brazil
}

ABSTRACT

\begin{tabular}{l|l}
\hline $\begin{array}{l}\text { Throughout the men's 2014 FIFA World Cup event in Brazil (WC-2014), there was } \\
\text { an ongoing reflexive debate that stated the possibility that FIFA, due to orders } \\
\text { imposed on the state of Brazil, slandered the country's national sovereignty. } \\
\text { However, FIFA's sovereignty concerning regulations and international football } \\
\text { championships is relativized when contrasted to that of the state. Having the WC- } \\
2014 \text { as a concrete object, the aim was to investigate how relations among sports } \\
\text { and politics occurred. A qualitative research study was used through the analysis of } \\
\text { documents and literature. It was verified that the WC-2014 event was fitting with } \\
\text { the patterns of transnational relationships, in which sovereign entities (the state and } \\
\text { FIFA) renounce a portion of their external sovereignty for mutual gain. The } \\
\text { misfortune appears when this gain is associated with leaders (political or sports) and } \\
\text { not the people, which can cause an internal sovereignty issue. Relating to the WC- } \\
\text { 2014, the counter-orders generated during the exception period were not due to } \\
\text { FIFA's interference in the national sovereignty, but to the illegitimacy / immorality } \\
\text { of the rulers who accepted the conditions of the transnational institution } \\
\text { serts, politics, mega-events, sports law. }\end{array}$ \\
\hline
\end{tabular}

\section{Introduction}

Throughout the men's 2014 FIFA World Cup event in Brazil (WC-2014), which involved candidacy, agreements with FIFA, the development of a new law, Law 12.663 (Brazil 2012), and the organization itself, there was an ongoing reflexive debate that stated the possibility that FIFA, due to the orders imposed by the state of Brazil, slandered the national sovereignty (National Popular Cup Committee Articulation 2011; Darn 2011).

FIFA's legitimacy to impose such demands on the WC-2014 has been a construct throughout the entity's history and its relation towards society. Furthermore, it has followed its own evolution and a sportive worldwide order which, at least in its official nature, created the path from a playful and informal standard to an institutionalized activity via free association (Miranda 2011; Prieto 2011; Silva 2006). Some institutions, such as FIFA when referring to football, acquired power over the regulations expedition to govern a certain sports modality in a formal way and under the organization of the main championships, which resulted in the achievement of sovereignty in the professional/official sportive field. 
In that way, FIFA, due to its legitimacy and power for "auctioning" the WC-2014 event to interested countries, imposed a series of guarantees to be provided. In Brazil, the Law 12.663 (Brazil 2012) was sanctioned as a way of implementing such guarantees in the Brazilian internal juridical planning, assuring the entity and the international community that the mega-event would meet the standards of quality required (Camargos \& Santoro 2012).

However, short of the direct incorporation of the guarantees requested by FIFA into the new law, there was a negotiation process in advance. Although FIFA had the legitimacy to present taxable conditions, due to the large number of people interested in its product, the institution cohabitated daily with adjustments to the public legal systems of the affiliated nations; it was therefore aware that relations with international entities require adjustments and concessions on both sides (Miranda 2011; Faria 2015). FIFA's sovereignty over international football rules and championships becomes compatible when compared to that of a nation.

Thus the aim of this essay is to distinguish the possible relations between sports and politics through some of the relations between the nation of Brazil and FIFA ahead of the 2014 World Cup in Brazil. It is presented as a qualitative delimitation in the research, adopting the analysis of documents such as laws, journalistic materials, dossiers, and a bibliography that in general mainly contains the following themes: sports mega-events; the World Cup; popular manifestations of 2013; international and transnational relations; sports law.

\section{Nation and sports mega-events - possible reasons}

World Cup editions have always had countries interested in its organization, even though there is not always the certainty of a positive cost-benefit, as Damo and Oliven (2012) have stated. Cornelissen (2012) argues that the quest to host a mega-event stems from ambitions and political motivations, arising both from the glimpse of political-partisan gains and the idea, albeit symbolic, of strengthening the nation, considering external relations with other sovereign entities (external sovereignty), and/or internal, within its own territory, in relation to its people (internal sovereignty) (Bonavides 2000). At the same time, the political-partisan play appears, which, in the sports sphere, is represented by the organizations of administration and sports practice.

The WC-2014 was a partnership between two private organizations (of sports administration), FIFA and the Brazilian Football Confederation (CBF, in Portuguese), in which the CBF, pleading for the exploration of the territory of professional/official football dominated by FIFA, appealed to the nation of Brazil for not only the concession of its territory, but also and mainly for its support and financing. According to Damo and Oliven (2013), the genesis of the Brazilian bid to host the WC-2014 occurred with the ambition of the then president of the CBF, Ricardo Teixeira, to become the president of FIFA. Hosting the WC-2014 in the country would strengthen the possibilities of his achieving such aspirations.

Therefore, Teixeira needed government support and relied on the political and personal interests of the then head of the Brazilian nation, President Lula, who was sympathetic to football and saw in it a great foreign policy opportunity (Damo \& Oliven 2013;Resende 2010). In this way, the process was facilitated by a change of attitude in the Labour Party (PT, in Portuguese), which was the agent at the time (the bid occurred in 2003) and, although it traditionally agreed with the left-wing part of the political spectrum and was typically against the realization of mega-events in the country, became supportive (Damo \& Oliven 2012, 2013).

In addition, a considerable number of deputies and senators somehow related to football (clubs, for example), which composed the parliamentary front called the "bench of the ball" (Bueno 2008; Mendes \& Codato 2015), contributed to a further increase in government sympathy for the WC-2014. This process did not only happen in relation to the WC-2014, but also during the construction of the Sports Ministry (SM), the ministry responsible for sports legislation in Brazil, through political-sport interrelationships based on exchanges of favors (Bueno 2008; Starepravo 2011).

According to Moreira (2012), relations between political and sports leaders are established in two ways: the instrumental, in which the politician approaches the sports organization with the intention of publicity, acquiring recognition and even respect and affection from partners and fans; and the affective, in which the politician approaches the sports organization by its particular identification, sometimes even using the state 
apparatus for its benefit. Likewise, it is not uncommon for the sports leader, enjoying popularity and symbolic and political capital (Bourdieu 2003) in the face of the political class itself, he become part of it.

As a result of personal and political interests, the state started to finance private sports in Brazil, especially high-income sports.

It is verified that, as the State incorporated sport (especially between the 1930s and 1980s), in search of symbolic and political strengthening, removing its control from civil society, at the same time, subsidized financially the private sector in a relation of clientelism. (Marchi Junior, Souza \& Starepravo 2014).

With the increasing commodification of sports and the country's democratic opening (at the end of the 1980s), the state began to reduce its intervention and offered grant autonomy to the private sector, making it part of the Brazilian Sports System (SBD, in Portuguese), offering conditions to influence national sports policies and assigning it the role of representation of the public power. However, public funding for private enterprise has not ceased (Marchi Junior, Souza \&Starepravo 2014).

Regarding soccer specifically, it is understood that this is the hegemonic sporting modality in Brazil, being the chief of the national sports organization, considered by Law 9.615 (Brazil 1998) as a part of Brazilian cultural heritage and of high social interest.

Considering this aspect of institutional protection and incentive, and the fact that professional/official football as a spectacular practice composes an important part of, if not the main part of, the sports industry, it is possible that political leaders glimpsed the accomplishment of the WC-2014 as being more important than their personal interests. With the belief that the mega-event could generate dividends for the country, high public investment, beyond what was traditionally done, would be justified.

According to Damo and Oliven (2013, p. 23):

"... rejection of the FIFA challenge would be unlikely since it disseminated the idea that the World Cup is an opportunity (not a burden), which is why only those who do not believe in their own capacity would be able to refuse it."

For Anjos, Dantas, and Santana (2013), the government would have felt compelled to hold the megaevent. That is, according to the authors, there is a political and social image created and/or encouraged by FIFA and the $\mathrm{CBF}$ in which the realization of the mega-event contributes to the strengthening of the national state and the imposition of sovereignty inside and outside the country, that is, of internal and external sovereignty.

According to Cornelissen (2012) and Resende (2010), the demonstration of external sovereignty through mega-events is a kind of "soft power" (symbolic). Above all, developing states, which have few possibilities for "strong power" (war power, international representation, etc.), seek to demonstrate symbolic power, to assert themselves on the world stage and to demonstrate reliability in the face of international relations. That is, through the mega-event, the country seeks to show to the world an economic and organizational capacity previously unknown, which would favor a protagonist within the continent, greater international visibility, and a better political-economic relationship, with increased possibilities for the creation of partnerships aimed at international investment, improvement of credit policies, attraction of tourists, etc.

In addition, in order to demonstrate its power vis-à-vis the international community, the country would invest heavily in improvements in urban infrastructure so that political and sports leaders and tourists in general would identify it with a developed country, especially one without problems related to the roads or airports. According to Cornelissen (2012) and Marchi Júnior et al. (2014), political and sports leaders use the idea of these gains (works, visibility, positive repercussions) related to the abstract concept of "legacies" as a justification for the great mobilization of public resources for mega-events. In coexistence with "material" or "tangible" legacies (infrastructure works, for instance) and/or when they are not visibly generated, such leaders begin to rely on "immaterial" or "intangible" legacies (increased culture, nationalism, appreciation of the country, etc.) to strengthen internal sovereignty, trying to overcome the weak relations between the state and its people that are often identified in developing countries (Anjos, Dantas \& Santana 2013; Rossetto Junior \& Paiva 2014).

In this case, the WC-2014 would serve mainly to reinforce the idea of a strong state and even a nation within its own territory, since all of the people would be encouraged to unite around the objective of demonstrating a great organizational capacity for the event and the reception of the international community, 
in addition to incorporating a possible sense of uniqueness with the aggregating object, "support" for the national team (Guedes 2013).

The problem is that, while the government sought to strengthen the state's internal sovereignty, relying on popular support, it showed disregard for the people, proving the capacity of resources to improve urban mobility and the construction of sports areas (either directly or through financing from the National Bank for Economic and Social Development - BNDES in Portuguese), while on a daily basis it claimed that it did not have the resources to meet social rights.

Of course, the relationship between one-off investments for the WC-2014 and everyday investments in other areas, especially social ones, is only relative. Capital expenditures in the social area require subsequent costing expenses, which is less so for infrastructure works. Besides that, the WC-2014 has the potential to attract, to a greater or lesser extent of what is said by the political and sports leaders, counterparts from the legacy. With a more structured and visible country attracting international capital, even the social area could be better served.

However, it appears that the perception of the population and common sense have not gone this way, establishing a cause-and-effect relationship between investments in the WC-2014 and lack of regard for social rights. According to the $117^{\text {th }}$ Survey conducted by the National Transport Conference (2014), 80.2\% of people, for example, disagreed with stadium constructions, believing that investments could be directed to more important areas. In this manner, the fortification of internal sovereignty risked a weakening setback.

\section{Popular manifestations and the World Cup in Brazil}

Regardless of whether a mega-event is held because of the personal ambitions or beliefs of the political class that tangible or intangible legacies will remain in the country, the fact is that the opinion of hosting megaevents is not unanimous among the population (National Transportation Conference 2014). There may be many reasons for the Brazilian case: the already a priori weakened relationship between government and society; the lack of attention to social rights; the propensity for corruption generated by the large financial contribution deposited in several areas in a short amount of time, making the supervision by control organs difficult; and the requirements of international sports management bodies.

Because of this, popular manifestations following the process of the organization of mega-events are not rare. These may take the form of marches or physical protests, or occur through social media (Damo 2013; Penteado 2014). In the case of the popular demonstrations held in Brazil in 2013duringthe Confederations Cup (CC-2013, test event for the WC-2014)in the period of the World Cup in South Africa, the population took to the street to question the gains generated by the mega-event for the population and the reasons why all of the public financial amounts were not invested in fundamental rights.

Realizing the risks of popular revolt and failure in the organization of the mega-event, the government authorities in the African country sought to treat the question of demonstrating internal sovereignty with great importance by using campaigns of promotion and loyalty by way of different governmental entities and large private companies in an attempt to influence the people (Cornelissen 2012). In the Brazilian case, presidential statements were broadcast in the media, affirming that possible new manifestations would be accepted, except for violent and illegal acts (Corrêa 2014). However, few physical manifestations occurred in 2014, in contrast to electronic protests (Penteado 2014).

In any case, it is important to understand the manifestations that occurred in 2013, mainly due to the fact that they were not reproduced in 2014 before or during the WC-2014. According to Guedes (2013), in 2013 there was no attempt to protest exclusively against the execution of sports mega-events related to FIFA. Actually, a minority of the protests occurred in relation to the occurrence of the CC-2013 and the WC-2014, the main focus being opposition to the increase in the cost of public transport fares in several cities across the country. This has been explained by Anjos, Dantas, and Santana (2013); Damo (2013); Penteado (2014); Pujol, Rocha, and Sampaio (2014); and Romão (2013), that reported the manifestations actually went through two moments: the first, which involved the protests against the increase in public transportation rates; and the second, with heterogeneous and/or generalized claims. 
In addition to the uprising in the face of the new prices, there was also the issue of the imminence of the vote in the National Congress of the Complementary Amendment Project Thirty-Seven (CAP37), which had as its object the withdrawal of the possibility of the Public Prosecutor's Office to conduct criminal investigations, leaving this role exclusively to the police. The inflation of the public transportation toll, the CAP37, and the realization of the WC-2014 thus impelled the people to question the corruption and legitimacy of governmental acts. The locus formed by the awakened popular feeling to protest against any fact that was bothering the individual or social group, so that the act of manifesting itself became more important than the very objectives of the manifestation, which also occurred through social media, was also explored by the media, especially in opposition to the power groups (Guedes 2013; Penteado 2014; Pujol, Rocha \& Sampaio 2014; Romão 2013).

According to Guedes (2013), the moment and the sentiment that brought the population together to protest are more relevant than the topics of the manifestations themselves. The union of the people around the national soccer team, mainly in the time of the WC-2014, was not a process determined exclusively by the cultural path (although it may not be ignored), but rather by the political route. As Starepravo (2011)states, the cultural identification of the population with the nationalistic feeling of "rooting for the soccer team," of the relation with the WC-2014, and even of the ostentation of great national sports symbols such as the great stadiums, for example, comes from a strong political intervention in the New State(Estado Novo, in Portuguese) period (1930s onwards), when a dictatorial government sought to strengthen the country's image, both internally and externally (attempted demonstration of soft state power), through sport.

However, what happened during the CC-2013 was that the same fact that united Brazilians in favor of a "patriotic pride" also contributed to a rebellion, specifically against the government. Damo (2013) also identifies a festive process of manifestation, in other words, in a period of traditional celebrations, such as the WC-2014 (and the CC-2013), for Brazilians, the protests were made with joy, and with the use of the flag colors, among other symbols, as if the population was cheering. As has been stated by Anjos, Dantas, and Santana (2013), the paths chosen by the protesters in the host cities of the WC-2014 were not random. They proceeded to the stadiums that hosted the games.

According to Guedes (2013), the main points of criticism regarding the WC-2014 in Brazil were the reform of the stadiums and the corruption associated with the urban reforms in general. At the same time, FIFA was seen as the one largely responsible for the amount of public money spent in social sectors, which was considered to be inappropriate, or even unnecessary, for the population. The implementation of the assignments required by the international entity, institutionalized in Brazil through the 12.663 Law (Brazil 2012), turned out to be a reverse reference to the lack of care for the needs of the population, as it was a cause and effect relationship. The internal sovereignty problems of popular dissatisfaction with governmental actions were transferred to an external sovereignty problem, as if an international entity (FIFA) was ruling the country. Therefore, part of the dissatisfaction against governments turned against FIFA.

Nevertheless, the common sense that seems to have guided some of the manifestations needs to be carefully analyzed. First, it should be noticed that FIFA, as a private international entity, does not have the means to oblige the national state to do something. If Brazil accepted that it would provide the required guarantees to FIFA in advance, it was by its own will. Besides that, although several points of the 12.663 Law (Brazil 2012) had revitalized the vested rights, it would not transgress constitutional rules, as was shown in the Direct Action of Unconstitutionality 4.976 (Federal Court of Justice 2014).

Therefore, even if the country had assumed FIFA's requirements in advance and, as Damo has stated (2012), nobody had taken them into consideration at the application period and they were presented as inconveniences only at the moment FIFA demanded them. The creation of the 12.663 Law (Brazil 2012) did not break the Constitution of the Federative Republic of Brazil (Brazil 1988), as it seems to have not broken national foreign sovereignty. This does not mean that this has not been relativized in some way, because the very process of relations between internal entities, governmental or nongovernmental, demands the negotiation and renunciation of part of external sovereignty for a greater purpose. 


\section{Sports and international relations between sovereign entities}

International relations demand many possibilities for the legal interference of a governmental entity such as states and intergovernmental organizations (the European Union, MERCOSUL, the UN, etc.) - or private entities with sovereignty over immaterial territories (international sports federations, for example) on others. This happens by means of treaties and agreements, among other instruments, as long as the international rules that are established are voluntarily accepted (Bonavides 2000; Miranda 2011; Faria 2015). The relationship between states and between states and intergovernmental organizations is called an "international right," whereas relations between states and private entities with power to enact rules beyond the territory in which they are located are called "transnational rights" (Faria 2015).

Thus, in the case of international rights, even if a state is sovereign over its territory, it may be that it renounces part of its sovereignty to incorporate the legal rules created by an international convention for the common benefit. In Brazil, international treaties, as long the state accepts them, acquire equivalence to ordinary national law. If they are about human rights, they acquire the status of constitutional norm, as determined by Article 5, § 4 of the Brazilian Constitution (Brazil 1988).

According to transnational rights, that is, the conciliation of legal state norms with non-state norms from private entities with transnational actuation, it is understood that the latter will only incorporate the country legislation if this is the state's wish, as well as in Law 12.663 (Brazil 2012). The simple acceptance of the international norm, without, however, its benefits in some way to the country's law, does not guarantee its effectiveness. In other words, the transnational norm only shows its effectiveness when a state concedes its conditions to do so (Faria 2015; Miranda 2011). In some cases, as in the law in question, its application can be done in an undetermined time, generating an exception period for any reason, but allowing it to be in force when this period ends.

The nature of the worldwide sports law itself is based on the conciliation of the internal rules of each state (public internal right) with the transnational rules provided by private institutions (external private right) in what concerns the sportive organization in itself in the realization of mega-events that include different countries. According to Miranda (2011), the worldwide sports law is ruled by a kind of "social contract," in allusion to Jean-Jacques Rousseau's theory. In this, in search for society law, each individual would wield a portion of their autonomy, their freedom, seeking for the state formation that would dictate social norms, which, at the same time, would restrict the individual liberty and guarantee the collective liberty. In the worldwide sports law, the sports entities' administration of each country would wield part of their liberty in dictating norms about the sport to the international federation (that, despite the name, is a private association located in a determined territory, but that issues transnational norms) "in favor of the creation of an entity that would be capable of harmonizing all the interests in this area" (Miranda 2011, p. 33).

As for the Brazilian state, article 217 of the Federal Constitution (Brazil 1988) guarantees the autonomy of organization to private sports entities, and in the $\S 1$ st of article 1 of Law 9.615 (Brazil 1988), it is established that "The formal sports practice of each modality, accepted by the respective national entities of sports administration" ends up imprinting the sports confederations as their representatives in the sports field. The acceptance of transnational rules by the federations, therefore, means state acceptance of the said rules, resulting in the validity of two simultaneous orders and characterizing the acceptance of the legal pluralism.

In this sense, when approaching the relation between the Brazilian state and FIFA, it is understood that it has sovereignty in the soccer professional/official territory and that the country does or does not accept what FIFA prevents. In fact, based on the assumption pointed to by Darn (2011) and weaving an analogy to Bonavide's (2000) concepts, FIFA territory can be considered the "soccer professional/official," whereas its "people" are characterized by the institutions and affiliated agents. FIFA's internal exercise of sovereignty in its territory, in this way, is given by the standardization of rules and by the organization and regulation of international championships, in the sense of the operation of competitions as well as in the structural conditions for such (Camargos \& Santoro 2012).

While its internal sovereignty can be freely exerted, the external sovereignty can be held down by the states that try to exert it. First, any institution is free to affiliate itself with FIFA or not and, in the case of opting 
for non-affiliation, the only possible sanction that can be imposed by the transnational institution is prohibition in the main international professional/official competitions under its organization. Second, even if the state passes to its national confederation (in the Brazilian case, the $\mathrm{CBF}$ ), the right and duty to obey the soccer international norms or not, this does not mean that it does not exert its discretion via public legal order.

In this way, as has been suggested by Miranda (2011) and Faria (2015), there are different ways to apply the transnational norms in the Brazilian territory, which the second author nominates "postures." By adopting Bobbio's (1996) referential, Miranda (2011) suggests the possibility of three postures: "refusal", "indifference", and "absorption". The first happens when the state perceives what comes from transnational planning as being prohibited. The second refers to the state's acceptance of another planning, but in a way that it does not ask the judiciary to resolve its conflicts. The third occurs when the state accepts the transnational planning, dividing in "reception", when the state expressly incorporates the non-state in its own planning, or "resend", when the state does not regulate the subject matter in its norms, but establishes the planning responsible for such.

According to Miranda (2011), the prevalent system in Brazil is resend, in the way that the norms emitted by FIFA about soccer are accepted by the CBF, regulating the "official" soccer at the national level, without the necessity of state norms. But other postures are not discarded, as in Law 12.663 (Brazil 2012), which states that due to the complexity and particularity of the subject it regulates (WC-2014), it deals with a majority case of reception, transforming the guarantees required by FIFA for the realization of the mega-event in national law, but also, even if to a lesser extent, of refusal, as not all the guarantees were integrally granted ${ }^{1}$.

In this way, we can notice that FIFA, regarding the exercise of external sovereignty, contrary to what happens in the states, necessarily subsumes other entities, above all the states themselves, and there is no way for FIFA to manifest itself independently, as it depends on acceptance. That is, even if FIFA determines the rules of official soccer and its respective official championships and thus has enough power over the states with which it negotiates, it can be barred by the states' will and laws.

If any point of Law 12.663 (Brazil 2012) and/or of the realization of the 2014 World Cup itself confronted society's acquired rights, it is not due to FIFA's interference on national sovereignty, but to the illegitimacy and immorality of the government that allowed it to do so.

\section{Final considerations}

The 2014 World Cup organization put itself as a very illustrative social locus of how relations between the state and sports work. From this, it is possible to realize that such relations are permeated by political exchanges that involve the abdication of part of the country's external sovereignty.

The public agent accepts such abdication as it believes there will be some personal benefits, normally related to a belief in the possibility of a better position before internal sovereignty by increasing its symbolic and political capital. On the other hand, this was not verified in the WC-2014, especially if the popular physical (CC-2013) and constant electronic manifestations are taken into account.

If in the transnational relations between the state and FIFA it appears at first sight that the will of the sports institution is the one that is highlighted, even with the accusation that FIFA is governing the country and taking national sovereignty, when examined again, we can identify that, in fact, FIFA demands generate effectiveness only if the government accepts them. Therefore, any identified problem does not concern the state's external sovereignty, but the internal one in the relationship between the government and the people.

\footnotetext{
${ }^{1}$ Free determination of the ticket price for the competitions, for instance, was demanded by FIFA, but the state refused to fully admit such possibility and established some criteria for different prices and discounts for certain groups of the population. Regardless of whether these criteria and discounts were ideal or not, the establishment by Law 12.663 (Brazil 2012) is an example that the state suffered no interference in its sovereignty by FIFA.
} 


\section{REFERENCES}

Anjos, L.A., Dantas, M.M., \& Santana, T.J.S. (2013). World Cup, manifestations and the occupation of the public space, Motrivivência, (41), 13-26. DOI: http://dx.doi.org/10.5007/2175-8042.2013v25n41p13.

Articulação Nacional dos Comitês Populares da Copa. (2011). Megaevents and Human Rights Violations in Brazil Dossier.

Bobbio, N. (1996) Theory of legal order. Brasília: Publisher of the University of Brasilia.

Bonavides, P. (2000). Political Science (10 a ed.). São Paulo: Malheiros.

Bourdieu, P. (2003). Symbolic Power. Rio de Janeiro: Bertrand Brasil.

Brasil. (1988). Constitution of the Federative Republic of Brazil 1988. Official Diary of the Union. Retrieved March 6, 2017, fromhttp://www.planalto.gov.br/ccivil_03/constituicao/constituicao.htm.

Brasil. (1998). Lei 9.615 de 24 de março de 1998. Institui normas gerais sobre desporto e dá outras providências. Official Diary of the Union. Retrieved March 6, 2017, from http://www.planalto.gov.br/ccivil_03/leis/19615consol.htm.

Brasil. (2012). Law 12.663 of July 5, 2012. Provides for the measures relating to the FIFA Confederations Cup 2013, the 2014 FIFA World Cup [...]. Official Diary of the Union. Retrieved March 6, 2017, fromhttp://www.planalto.gov.br/ccivil_03/_ato2011-2014/2012/Lei/L12663.htm.

Camargos, V.M. \& Santoro, L.F.G. (2012). General Law of the Commented Cup - Law 12.663/2012 and complementary standards. São Paulo: Revista dos Tribunais.

Bueno, L. (2008). Public policies of sport in Brazil: reasons for the predominance of high income. Doctoral dissertation, Escola de Administração de Empresas de São Paulo da Fundação Getúlio Vargas, São Paulo, Brasil.

Confederação Nacional do Transporte. (2014). $117^{a}$ Pesquisa CNT/MDA. Retrieved May 26, 2017, fromhttp://www.cnt.org.br/Imagens\%20CNT/PDFs\%20CNT/Pesquisa\%20CNT\%20MDA/Relatorio\%20SINTESE\%20 -\%20CNT\%20FEVEREIRO2014\%20-\%20R117\%20-\%20FINAL.pdf.

Cornelissen, S. (2012). The mega sporting events as big political projects. An interpretation of the 2010 FIFA World Cup in South Africa. In R.L. Goig (Ed.), Megaeventos deportivos - perspectivas científicas y estúdios de caso (pp. 187-208). Barcelona: UOC.

Corrêa, C. (2014). Minister of Justice speaks of the measures to be adopted during eventual popular demonstrations in the World Cup. Retrieved January 29, 2015, fromhttp://www.esporte.gov.br/index.php/multimidia/118-lista-radioesporte/47237-ministro-da-justica-fala-das-providencias-a-serem-adotados-durante-eventuais-manifestacoes-popularesna-copa-do-mundo.

Damo, A.S. (2012). The desire, the right and the duty - The plot thatbrought the World Cup to Brazil [Versão eletrônica], Movimento, 18(2), 41-81.

Damo, A.S. (2013). The Demonstrations Cup - elective affinities between mega-events. Anais do $37^{\circ}$ Encontro Anual da Associação Nacional de Pós-Graduação e Pesquisa em Ciências Sociais (Anpocs), Águas de Lindóia, Brasil.

Damo, A.S.\& Oliven, R.G. (2012). The "great occasion": Brazil to host the 2014 FIFA World Cup and the 2016 Olympic Games. In R.L. Goig (Ed.), Megaeventos deportivos - perspectivas científicas y estúdios de caso (pp. 227-245). Barcelona: UOC. p. 227-245.

Damo, A.S.\& Oliven, R.G. (2013). Brazil on the horizon of the 2014 and 2016 sports mega events: its face, its partners and its businesses [Versão eletrônica], Horizontes Antropológicos, 19(40), 19-63.

Darn, T. (2014). Reflections on the territory of football and the 2014 FIFA World Cup in Brazil. Doctoral dissertation.Universidade Estadual Paulista Júlio de Mesquita Filho, Rio Claro, Brasil.

Faria, T.S. (2015). The influence of transnational sports law in brazilian law: from law reproduction to directly application by state jurisdiction. Revista de Direito Internacional, 12(2),324-340. DOI: http://dx.doi.org/10.5102/rdi.v12i2.3569.

Guedes, S.L. (2013). Brazil reinvented - notes on demonstrations during the Confederations Cup [Versão eletrônica], Nueva Sociedad, (248), 89-100.

Marchi Junior, W., Bolsmann, C., Almeida, B.S., \& Souza, J. (2014). FIFA World Cup in South Africa 2010: How was this experience and what can we learn with it? [Versão eletrônica], Movimento, 20(2), 711-733.

Marchi Junior, W., Souza, J., \& Starepravo, F.A. (2014). Sport of social inclusion: reflections on Brazil Sportive of megaevents. In A. Marinho, J.V. Nascimento, A.A.B. Oliveira (Org.). Legados do esporte brasileiro (pp. 519-559). Florianópolis: Editora da Udesc. 
Mendes, A.\& Codato, A. (2015). The institutional configuration of sport policy in Brazil: Organization, evolution and dilemmas. Revista de Administração Pública, Rio de Janeiro, 49(3), 563-93.DOI: http://dx.doi.org/10.1590/00347612125903.

Miranda, M.N. (2011). The Law in sport (2 ${ }^{\mathrm{a}}$ ed.). Rio de Janeiro: Lumen Juris.

Moreira, M.V. (2014). Electoral game and politics relations in the Argentinian football [Versão eletrônica], História: Questões\& Debates, 57(2), 127-149. DOI: http://dx.doi.org/10.5380/his.v57i2.30577.

Penteado, C. (2014). The protests against the 2014 World Cup in Brazil: analysis of the II great act against the Cup in facebook. Em Debate, 6(1), 7-23.

Prieto, L.M. C. (2013). Sport and state. Revista Aranzadi de Deporte y Entretenimiento. Monografia num. 8 (2 ${ }^{\mathrm{a}}$ ed.). Cizur Menor: Thomson Reuters.

Pujol, A.F.T., Rocha, F.G., \& Sampaio, F.S. (2014). Popular manifestations in Brazil today: civil society in network and claims on political power. Anais do $12^{\circ}$ Coloquio Internacional de Geocrítica, Barcelona, Espanha.

Resende, C.A.R. (2010). Sports in Lula's Foreign Policy: the important thing is to compete? [Versão eletrônica], Boletim Meridiano 47, 11(122), 35-41.

Romão, W.M. (2013). \#naovaitercopa: manifestations, World Cup and 2014 elections [Versão eletrônica], Revista Agenda Política, 1(2), 152-167.

Rossetto Junior, A.J.\&Paiva, R.P. (2014). FIFA World Cup 2014: impacts on Brazilian sports. Anais do $5^{\circ}$ Seminário Nacional Sociologia \& Política, Curitiba, Brasil.

Supremo Tribunal Federal. Direct Action of Unconstitutionality 4.976 (2014) Brasília. Retrieved January 29, 2015, from http://www.stf.jus.br/arquivo/cms/noticiaNoticiaStf/anexo/ADI_4976_VOTO_MRL.pdf.

Starepravo, F.A. (2011). Public policies of sport and leisure in Brazil: approximations, intersections, ruptures and estrangements between political / bureaucratic and scientific / academic subfields. Doctoral dissertation. Universidade Federal do Paraná, Curitiba, Brasil.

Australian Bureau of Statistics. (2012). Sports and Physical Recreation: A Statistical Overview, Australia, 2012. Canberra, Australia.

Brusted, J.R. (1993). Who will go out and play? Parental and psychological influences on children's attraction to physical activity. Pediatrics Exercise Science, 5(3), 210-223.

Chan, D.K., Lonsdale, C., \& Fung, H.H. (2012). Influences of coaches, parents, and peers on the motivational patterns of child and adolescent athletes. Scandinavian Journal of Medicine \& Science in Sports, 22, 558-568.

Cote, J. (1999). The influence of the family in the development of talent in sport. The Sport Psychologist, 13, 395-417.

Currie, J. (2009). The relationship between sport and children's mental health. Education Connect, 14, 14-15.

Griffin, R.S. (1998). Sports in the lives of children and adolescents: Success on the field and in life. Westport: Praeger.

Hardy, L., Kelly, B., Chapman, K., King, L., \& Farrell, L. (2010). Parental perceptions of barriers to children's participation in organised sport in Australia. Journal of Paediatrics and Child Health, 46, 197-203.

Hesketh, K., Waters, E., Green, J., Salmon, L., \& Williams, J. (2005). Healthy eating, activity and obesity prevention: a qualitative study of parent and child perceptions in Australia. Health Promotion International, 20(1), 19-26.

Independent Sport Panel. (2009). The future of sport in Australia. Canberra: Commonwealth of Australia.

Lee, S. (2009). Adam Scott gets back on course. Retrieved from http://www.dailytelegraph.com.au/news/adam-scottgets-back-on-course/story-e6frewt0-1225796433521

Leff, S.S., \& Hoyle, H.R. (1995). Young athletes' perceptions of parental. Journal of Youth and Adolescence, 24(2), 187203.

Moore, L.L., Lombardi, D.A., White, M.J., Campbell, J.L., Oliveria, S.A., \& Ellison, R.C. (1991). Influence of parents' physical - activity levels on activity levels of young children. The Journal of Pediatrics, 118(2), 215-219.

Nezhad, M., Rahmati, M., \& Nezhad. M. (2012). Relationship between social-economic status of family and adolescents' student sport participation. Scholars research library, 3(8), 4012-4016.

Office for Recreation and Sport. (2010). Trends in Recreation and Sport. Adelaide: Government of South Australia.

Smolicz, J.J., \& Secombe, M.J. (1981). The Australian school through children's eyes. Melbourne: Melbourne University Press. 
Smolicz, J.J., \& Secombe, M.J. (1986). Italian language and culture in South Australia: A memoir approach. In C. Bettoni (Ed.), Altro Polo: Italians abroad: Studies on language contacts in English speaking countires (pp. 27-60). Sydney: Frederick May Foundation for Italian Studies: University of Sydney .

Smolicz, J.J., \& Secombe, M.J. (1989). Types of language activation and evaluation in an ethnically plural society. In U. Ammon (Ed.), Status and fuction of language and language varieties (pp. 478-514). Berlin: de Gruyter.

Taylor, T. (2000). Women, sport and ethnicity: Exploring experiences of difference in netball. (Unpublished PhD Thesis), University of New South Wales, Sydney.

Wheeler, S. (2011). The significance of family culture for sports participation. International review for the sociology of sport, 2(47), 235-252.

Wright, J., MacDonald, D., \& Groom, L. (2003). Physical activity and young people: Beyond participation. Sport, Education and Society, 8/1, 17-33.

AUTHOR'S ADDRESS: Felipe Canan

Colombo Avenue

Physical Education Department (M06)

State University of Maringá

Maringá, 5790, Brasil

E-mail: felipe.canan@gmail.com

Received: 16 March 2018; Accepted: 7 May 2018 